THE TYNDALE BIBLICAL THEOLOGY LEGTURE, I 967

\title{
THE SERVANT OF THE LORD IN THE TEAGHING OF JESUS
}

By R. T. FRANGE

The Christian church has always prized the 'Servant Songs' of Isaiah, and especially chapter 53 , with its picture of innocent and vicarious suffering and death, as one of the clearest foreshadowings of the redemptive work of Christ to be found in the Old Testament. It has, moreover, been generally assumed that this understanding of these passages goes back to Jesus Himself, who knew Himself to be the one there predicted, and deliberately set Himself to fulfil this vocation. When $\mathrm{He}$ told His disciples that He must be rejected and killed, Ghristian interpreters have seen here a mind steeped in Isaiah 53. Thus G. R. North could write in 1948 , 'It is almost universally admitted that Jesus saw His way by the light that Isa. liii shed upon His predestined path.'1

But those words could not have been written today. This understanding of Jesus' view of His mission has come under strong attack, particularly on two fronts. From the school of Bultmann has come the (predictable) insistence that this developed soteriology betrays the mind of the early church, not that of its Founder, and the consequent denial of the authenticity of most or all of the relevant sayings of Jesus, generally as vaticinia ex eventu. This school of thought is now familiar enough to us. To answer such contentions requires more than an exegetical exercise; it demands that we lay bare the basic presuppositions on which we conduct our New Testament criticism and exegesis, and this lecture does not allow so lengthy a procedure. While some consideration will be given individually to the arguments against the authenticity of the main passages studied, our purpose here is to concentrate

1 C. R. North, The Suffering Servant in Deutero-Isaiah, Oxford University Press (1948) 218. 
on the second main line of attack, which is both more recent, and also of more interest to biblical theology, for here the traditional approach is rejected not on critical but on exegetical grounds. By and large, the authenticity of the relevant sayings is assumed; it is their dependence on Isaiah 53 which is called in question.

The principal manifesto of this school of thought is Morna Hooker's book, Fesus and the Servant. ${ }^{2}$ She traces its ancestry to Jackson and Lake in $1920,{ }^{3}$ but it has come to the fore in more recent years especially in the work of G. F. D. Moule, ${ }^{4}$ G. K. Barrett, ${ }^{5}$ and Dr. Hooker herself. ${ }^{6}$ It is with these three authors that we shall be particularly concerned.

Professor Moule's article is concerned with the theme of the vindication of the oppressed and rejected in the New Testament. He finds the major Old Testament background to this in Daniel 7. What Daniel 7 does not contain, however, is the idea of redemption through the suffering of the one so vindicated. Only where this idea is found in the New Testament, he argues, is it necessary to postulate the use of Isaiah 53. And in the Synoptic sayings of Jesus he finds this idea of redemptive suffering only in Mark 10:45 (the 'ransom' saying) and Mark 14:24 (the Words of Institution), neither of which he regards as a clear allusion to Isaiah 53. Professor Moule concludes that the early church (and presumably Jesus, though Moule does not say so) thought more in terms of the vindication of Jesus than of redemption through His death, an idea which only became explicit in the teaching of Paul, and that Daniel 7 is therefore the chief, if not the only, source of Jesus' idea of a suffering Son of man.

Professor Barrett deals in detail with Mark 10:45 (the 'ransom' saying), in terms of both its language and its thought,

2 M. D. Hooker, Fesus and the Servant, SPGK, London (1959).

3 F. J. F. Jackson and K. Lake, The Beginnings of Christianity: Part $I$, The Acts of the Apostles, vol. I, Macmillan, London (1920) 383-392. Dr Hooker, op. cit., 3-5, mentions also F. G. Burkitt, H. J. Cadbury, W. Bousset, and R. Bultmann as exponents of this approach.

4 C. F. D. Moule, 'From Defendant to Judge-and Deliverer: an Enquiry into the Use and Limitations of the Theme of Vindication in the New Testament', Studiorum Novi Testamenti Societas Bulletin 3 (1952) 40-53.

${ }^{5} \mathrm{C}$. K. Barrett, 'The Background of Mark ro: $45^{\prime}$ ', in New Testament Essays: studies in memory of T. W. Manson, ed. A. J. B. Higgins, Manchester University Press (1959) I-18.

6 Cf. also G. T. Craig, Fournal of Religion 24 (1944) 240-245; J. Knox, The Death of Christ, Collins, London (1959) 106-109; R. H. Fuller, The Foundations of New Testament Christology, Lutterworth, London (1965) I $15^{-1} 19$. 
and concludes that the primary Old Testament background to this particular saying lies in Daniel 7, not in Isaiah 53 .

Dr Hooker lays down certain criteria for recognizing a use of the Servant idea in the New Testament. ${ }^{7}$ They may be summarized as follows: (a) It must 'be shown that the language and ideas found in the New Testament reference have come from, and could only have come from, that particular Old Testament passage'; (b) Such words must, both in the Old and the New Testament, apply 'to the person or mission of the central figure'; (c) The reference must be to what are 'the significant features of the prophecy', viz. the suffering and death of the Servant; (d) If no supposed allusions pass these tests, Jesus' expectation of suffering must be explained from some other source; if, however, some do pass, there is still the possibility that 'Jesus saw himself, not primarily as the Servant, but as one greater than the Servant, who included in himself the attributes of that figure'. Our criticisms of these criteria will become apparent in what follows. They are apparently designed to exclude as much as possible, to allow only the irreducible minimum of references to the Servant, rather than to arrive at what is, on balance, the most probable explanation of Jesus' expectation of His suffering. This impression is heightened when the succeeding study is found to treat the individual allusions in isolation, without consideration of their cumulative effect. Jeremias' criticism is that 'She treats the New Testament like a mosaic, and examines each stone separately' ${ }^{8} \mathrm{Dr}$ Hooker's conclusion is that Jesus' announcements both of the fact and the meaning of His death do not show the influence of the Servant Songs; 'the reference is in every case a general one to the necessity which is laid upon him by the divine will, and which is expressed in Scripture as a whole'.9 The major source of this conviction Dr Hooker, like Moule and Barrett, finds in the figure of the Son of man in Daniel 7, who, as the representative of his people, must share their sufferings. ${ }^{10}$

One of Dr Hooker's arguments, with which we have not the space to deal in this lecture, is that the Servant of Yahweh was not intended to be a messianic figure in Isaiah, and was not so understood at the time of Jesus, at least as far as the idea of

7 Op. cit., 62-64.

${ }^{8} \mathrm{~J}$. Jeremias, $\mathcal{F} T S$ in (1960) I 42 .

Op. cit., $149-150$.

10 Ibid., $159-163$. 
vicarious suffering is concerned. Both these points are highly controversial, and have been decisively rejected, with voluminous evidence, by Zimmerli and Jeremias. ${ }^{11}$

The main question with which we must concern ourselves is this: Do the sayings of Jesus in fact allude to the Servant figure, or show a dependence on Isaiah 53 ? And if this figure was in His mind, did His emphasis fall on the theme of suffering, especially of vicarious and redemptive suffering?

Before we embark on a study of the relevant sayings individually, the allusive character of the majority of them requires some comment. It will be clear from what has been said that for Moule, Barrett, and Hooker mere verbal allusion is not sufficient to establish that Jesus interpreted His mission as that of the Servant; what is required is deliberate quotation with a clear intention to provide a theological explanation of $\mathrm{His}$ approaching death in redemptive terms. ${ }^{12}$ This demand, however, is more convenient than realistic. The extent to which Old Testament concepts permeated the teaching both of Jesus and of the early church demands that we take allusions seriously as evidence of the thought which gives rise to them. To fail to do so is to ignore a large part of the evidence. ${ }^{13}$ Moreover, to many scholars the very allusiveness of the references is evidence not only of the extent to which the Servant figure dominated Jesus' view of His mission, but of the authenticity of the sayings concerned. If the Servant idea were an alien concept introduced into the sayings of Jesus by early Christian thought, it is hardly likely that it would be so unobtrusively woven into the Gospel material. ${ }^{14}$

${ }^{11} \mathrm{~W}$. Zimmerli and J. Jeremias, The Servant of God (revised edition), SCM, London (1965) $11-79$. This is a revised ET of their article maîs $\theta$ eov in TWNT V 653-713.

${ }_{12}$ The following words of M. D. Hooker, op. cit., I55, make the point explicit: 'In the absence of any passage in the primitive tradition which clearly applies Isa. 53 to the meaning of Christ's death, and not merely the fact of that event, it is impossible to accept linguistic similarity as evidence that any connection was intended doctrinally with the Servant concept.' $C f$. Moule's search for allusions 'to the redemptive work of the Servant' (loc. cit., $5 \mathrm{I}$; our italics), ignoring other suggested allusions to the Servant, even to the aspect of suffering, if it is not explicitly redemptive.

18 So especially H. W. Wolff, Jesaja 53 in Urchristentum ${ }^{2}$, Evangelische Verlagsanstalt, Berlin (1950). Cf. J. Jeremias, The Servant of God, 88 and n. 392a; H. E. W. Turner, Fesus, Master and Lord ${ }^{2}$, Mowbrays, London (1954) 205-209; idem, Historicity and the Gospels, Mowbrays, London (1963) 85. For the same emphasis with regard to the Old Testament allusions in general see R. H. Gundry, The Use of the old Testament in St. Matthew's Gospel, E. J. Brill, Leiden (1967) 2-5.

14 'It is probable that the Servant-conception would be much more obvious in the Gospel tradition if it were not an authentic element which goes back to Jesus 
In our treatment of the individual sayings, we shall deal first with the one formal quotation of Isaiah 53 attributed to Jesus; then with the two verbal allusions which are so clear as to be, in our view, indisputable; thirdly with other suggested allusions to the language of the Servant Songs. We shall then consider the supporting evidence of Jesus' undoubted use of Isaiah 6r:I-3; and finally we shall look at the numerous predictions of His suffering which, while not verbal allusions, are commonly regarded as based on Isaiah 53. We shall deal only with the sayings of Jesus in the Synoptic Gospels; a consideration of the Fourth Gospel is beyond the scope of this lecture, but would in fact add little for or against the position here advocated. It will be noticed that almost all the relevant material is concerned with Isaiah 52:13-53:12, the one passage in which the vicarious suffering of the Servant comes into clear focus. Thus our argument does not depend on the assumption, questioned by Dr Hooker, ${ }^{15}$ that the four Servant Songs isolated by Duhm were known as such in Jesus' day. A few possible references to Isaiah 42:I-6 may be seen, but these are peripheral to the argument. It is the use of the key passage Isaiah 52:1353:12 which is principally our concern.

\section{A. INDIVIDUAL QUOTATIONS AND ALLUSIONS}

\section{The One Formal Quotation (Luke 22:37)}

Jesus' words in support of His command to the disciples to arm themselves before leaving the Last Supper, recorded only

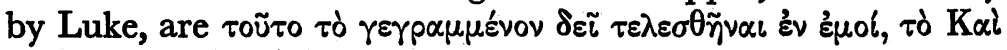

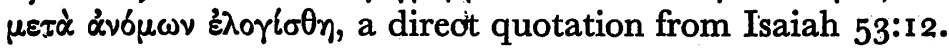

The authenticity of the saying has been questioned, though actual arguments are few. ${ }^{16}$ It is said to be obscure and clumsily constructed, ${ }^{17}$ though why this should mark it as a later addition is not explained. The chief objection is to its context: J. M. Creed thinks it unlikely that Jesus could have entertained the

Himself', V. Taylor, Fesus and His Sacrifice, Macmillan, London (1937) 47-48. See more fully his article, 'The Origin of the Markan Passion-Sayings', NTS I (1954-55) 159-167, especially p. 163. Cf. also B. Lindars, New Testament Apologetic, SCM, London (196r) 77-79; J. L. Price, Interpretation 12 (1958) 35.

15 Op. cit., 25-30, 61, . 155-1 58 .

16 F. J. F. Jackson and K. Lake, op. cit., vol. 1,390 , simply assume its inauthenticity; also M. D. Hooker, op. cit., 86.

${ }_{17}$ J. M. Greed, The Gospel according to St. Luke, Macmillan, London (1930) 270. 
thought of armed resistance. ${ }^{18}$ It is, however, even more unlikely that the early church could have attributed to Him a thought so out of character and so embarrassing to Christian apologetics; the words of verse 36 are best explained as a metaphorical warning of dangerous times ahead. ${ }^{19} \mathrm{~J}$. Jeremias sees the 'quite obviously ancient' context as a principal argument for the authenticity of the saying, ${ }^{20}$ and its Semitic origin is indicated by the phrase $\mu \varepsilon \tau \dot{\alpha} \alpha \nu \delta \mu \omega v$, which is independent of the LXX

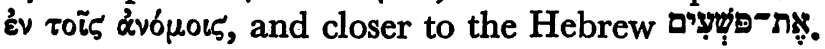

But does this quotation warrant the conclusion that Jesus believed that $\mathrm{He}$ was fulfilling the redemptive role of the Servant? H. J. Cadbury ${ }^{21}$ states that Luke, 'the one time that he does quote Isaiah liii almost unbelievably escapes all the vicarious phrases with which that passage abounds', and draws the conclusion that Luke 22:37 is no indication of a use of Isaiah 53 to explain Jesus' death in terms of vicarious suffering. ${ }^{22}$

Two factors, however, tell against this conclusion. The first is the context: that Jesus on the eve of His death should apply Isaiah 53 to Himself at all is surely significant, and indicates that $\mathrm{He}$ saw His death in the light of that chapter; that $\mathrm{He}$ should quote the phrase 'was numbered with the transgressors', far from indicating that vicarious suffering was absent from His mind, shows that $\mathrm{He}$ was preoccupied with the fact that $\mathrm{He}$, who least deserved it, was to be punished as a wrongdoer. The words immediately following in Isaiah 53:1 2 make the vicarious nature of the suffering explicit. ${ }^{23}$

The second factor is the formula with which Jesus introduces

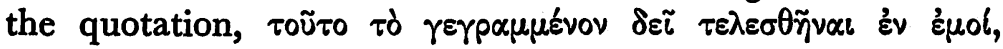

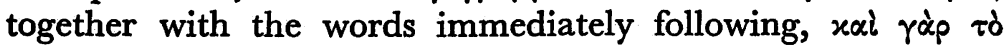

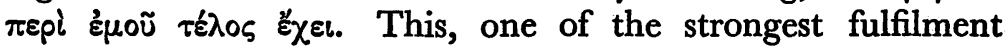
formulae ever uttered by Jesus, is hardly the way to introduce a casual catch-phrase. If Jesus saw these words as written about $\mathrm{Him}$, and destined to be fulfilled in Him, it is hard to avoid the conclusion that $\mathrm{He}$ identified Himself with the one of whom

18 Ibid., 270.

10 Cf. F. C. Burkitt, The Gospel History and its Transmission, T. and T. Clark, Edinburgh (1906) 140-142.

so The Servant of God, r05. $C f$., for the appropriateness of the quotation by. Jesus in this setting, V. Taylor, Jesus and His Sacrifice, 191-194; idem, Behind the Third Gospel, Clarendon Press, Oxford (1926) 267-268.

\&i H. J. Cadbury, in F. J. F. Jackson and K. Lake, op. cit., vol. 5, 366; cf. idem, The Making of Luke-Acts, Macmillan, London (1927) 280 and n. 2 ad loc.

"a $C$. M. D. Hooker, op. cit., 86.

${ }^{2}$ Cf. V. Taylor, Jesus and His Sacrifice, 194. 
they were written, the Servant of Yahweh, whose vicarious suffering $\mathrm{He}$ was about to undergo.

\section{The Two Clear Allusions}

\section{(a) Mark 10:45}

The arguments which used to be directed against the authenticity of this verse as a whole are now more specifically applied

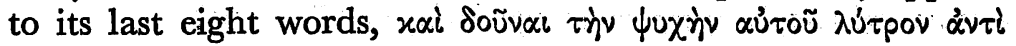
$\pi 0 \lambda \lambda \tilde{\omega} \nu$, which are separated off by H. E. Tödt, followed by R. H. Fuller, ${ }^{24}$ as a Palestinian gloss ${ }^{25}$ on a genuine saying of Jesus about Christian ideals of service. Tödt's three arguments may be summarized as follows: (i) the offending words introduce a concept alien to Jesus' thought; (ii) their absence in the Lucan parallel (Luke 22:27) proves their dispensability; (iii) their content is inconsistent with the preceding discourse; representing, as Wellhausen remarked, ${ }^{26}$ a $\mu \varepsilon \tau \dot{\alpha} \beta \alpha \sigma i \varsigma$ sis $\alpha^{3} \lambda \lambda \dot{o}^{\circ}$ $\gamma$ ช́vos. These arguments must be briefly considered.

(i) Tödt has wisely dropped the contention of earlier critics that these words are a distillation of Pauline theology;27 as A. Richardson points out, the word $\lambda v^{\tau}$ pov is not Pauline. ${ }^{28}$ But Tödt contends that the idea of a vicarious death occurs nowhere else in the Synoptic Son of man sayings. It does, however, occur in the Words of Institution, and is probably implied, as we have seen, in Luke 22:37. In any case, it is an indefensible criterion of authenticity which rejects a saying simply because it has no parallel. Moreover, the enigmatic and reserved character of the saying is not what one would expect in a deliberate distillation of the theology of the apostolic church. ${ }^{29}$

(ii) While we may grant that the discourse would not be noticeably incomplete without the last eight words, it must be

24 H. E. Tödt, The Son of Man in the Synoptic Tradition, ET, SGM, London (1965) 203-2II; R. H. Fuller, Foundations, I 18.

${ }_{25}$ That it is at least Palestinian is proved by the linguistic features. $C f$.J.Jeremias, The Servant of God, 9o; and, in detail, idem, The Eucharistic Words of Jesus', ET, SCM, London (1966) 179-182. Cf. also H. E. Tödt, op. cit., 202-203, 205.

${ }_{26}$ J. Wellhausen, Das Evangelium Marci, Georg Reimer Verlag; Berlin (1903) 91 .

27 See e.g. H. Rashdall, The Idea of Atonement in Christian Theology, Macmillan, London (1919) 50-51.

${ }_{28}$ A. Richardson, An Introduction to the Theology of the New Testament, SCM, London (1958) 220. Cf. R. H. Fuller, The Mission and Achievement of Fesus, SCM, London, (1954) 57. For Fuller's later views see below n. 65 .

20 V. Taylor, Fesus and His Sacrifice, 105. 
observed that Luke 22:25-27 is anything but a close parallel to the present passage, and must, as Tödt himself recognizes, ${ }^{30}$ be regarded as 'later and secondary', 31 if not as a separate tradition. It cannot, therefore, be used to control the content of the Marcan passage.

(iii) It is true that the preceding words have not been concerned with a vicarious death, but with the true nature of Christian leadership, which is characterized as service; Jesus appeals for a revolution in His disciples' idea of what constitutes greatness, and appeals to His own example. That He should go on, however, to reinforce His appeal by the concrete example of His approaching death is by no means inconsistent. Mark I0:32-34, $3^{8}$ show that the passion was already in His mind, and it illustrated His point excellently. To be great was, for Jesus, to serve, to be humiliated. His great act of service was to be in the humiliation of His death for the redemption of others, the very antithesis of the world's idea of greatness. The logic of the sentence does not demand, as Tödt alleges, ${ }^{32}$ that His disciples too should give their lives as a ransom for many. This is simply a topical, though unique, example of the humble, self-denying service to which $\mathrm{He}$ called them. ${ }^{33}$

We must now attempt to answer Professor Barrett's detailed arguments against the dependence of this phrase on Isaiah $53 .{ }^{34}$ Like him, we shall examine the wording piecemeal, but we shall not attempt, as he does, to separate the linguistic parallels from the parallels of thought. In some cases it is the latter which give point to the former, and Barrett's treatment obscures this point. We shall, therefore, use the verbal echoes as springboards for a consideration of the parallel ideas. ${ }^{35}$

We may begin with the idea of service, and the verb

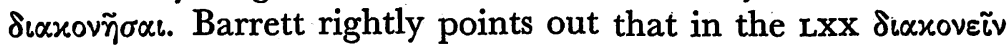
and its cognates never translate while there is thus no verbal echo of the Lxx of Isaiah 52-53 in this word, it is not improbable that the Aramaic expression

${ }^{80}$ H. E. Tödt, op. cit., 202-203.

s1 R. H. Fuller, Mission and Achievement, 57.

32 H. E. Tödt, op. cit., 207.

${ }^{33} C f$. W. F. Howard, ExpT 50 (1938-39) I 10; $f f$. also M. D. Hooker, op. cit., 78.

34 G. K. Barrett, loc. cit., especially 2-7. 42 , insists that the latter rather than the former determine the existence of an intentional allusion. His detailed treatment of Mk. 10:45 (ibid., 41-47) follows similar lines to those here proposed.

${ }^{86}$ C. K. Barrett, loc. cit., 4. 
of Jesus was a more direct echo of the רֶֶ of Isaiah 42:I; 52:13

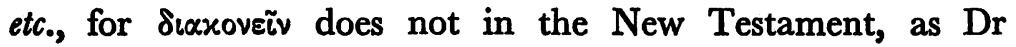
Hooker alleges, ${ }^{37}$ always, or even usually, denote specifically domestic service. ${ }^{38}$ That it does not indicate this in Mark 10:45 is shown both by the fact that it is there used in a discussion of supposed superiority and inferiority, the latter being denoted

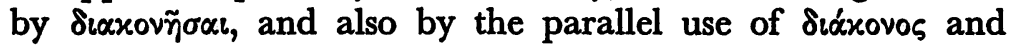

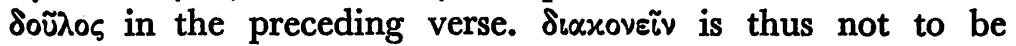

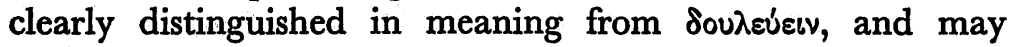
well indicate an underlying echo of עִקֶ. The parallel is, however, not complete, for whereas the Servant in Isaiah is the Servant of Yahweh, Jesus is speaking in Mark 10:45 of service to $m^{2 n^{39}}$ (though in fact the Servant in Isaiah did benefit men by his suffering, and Jesus did accept His suffering in.obedience to the will of God). ${ }^{40}$ So while Jeremias' confident assertion that

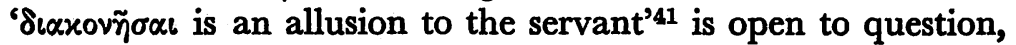
a loose connection of thought seems probable.

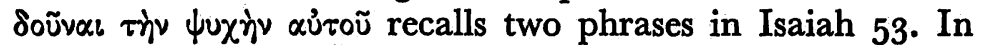
verse 10 the phrase

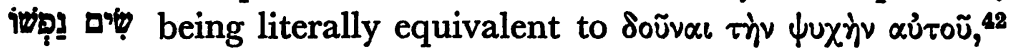
and the parallel being further reinforced by the connection between does not notice this parallel, but confines his attention to the echo in verse 12, where he stresses that the Hebrew expression

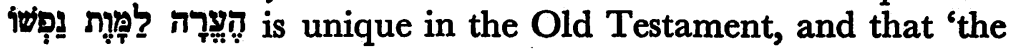
word lammaweth is generally excised by editors on metrical grounds'. ${ }^{44}$ This latter point is clearly irrelevant for our purpose, since there is no evidence for the absence of תִִ̣ from any ancient text; it must have been there in Jesus' day. The uniqueness of the expression is also scarcely relevant, as both

37 Op. cit., 74 .

88 This primary sense is less frequent than a general sense of service to others. Domestic service cannot be intended in Jn. 12:26; I Pet. 1:12; 4:10. For many other examples see Arndt 183 .

${ }^{39}$ Cf. M. D. Hooker, op. cit., 74-75.

$40 \mathrm{Dr}$ Hooker's contrast (op. cit., 75) between the abject and enforced suffering of the Servant and the willing service of $\mathrm{Mk}$ 10:45 is forced. Both Jesus and the Servant suffered according to the will of God ( $c f$. Is. 53:4, 6, 10).

41 The Servant of God, 100.

42 The Vulg. rendering, si posuerit pro peccato animam suam, adopted by RsV, makes the parallel closer, the third person verb making the action reflexive, as it is in

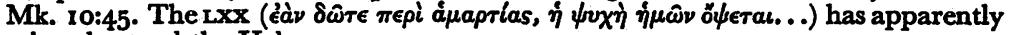
misunderstood the Hebrew.

${ }^{\star 3} C f$. R. H. Fuller, Mission and Achievement, 57; J. Jeremias, The Servant of God, 96.

"Loc. cit., 4-5. 
the Lxx and the Targum are quite clear as to its meaning, and render it prosaically in exactly the sense of these words of Jesus. ${ }^{45}$ Thus Jesus' words here echo quite closely two parallel expressions for the Servant's acceptance of death in Isaiah 53, and it is clear that the idea of a voluntary giving up of life is essential to the thought of that chapter as a whole.

The following words are really inseparable from those which precede, but separate treatment may serve to clarify the issues. We turn now to the expression $\lambda u ́ \tau p o v$ a'vi', 'a ransom instead of'. Jeremias sees here 'a free translation of meaning of "compensation")'.46 in Isaiah 53:10 to explain the purpose of the Servant's death) is never translated in the Lxx by $\lambda u$ ipov, which generally translates the roots 2 גדה . Professor Barrett ${ }^{47}$ and Dr Hooker ${ }^{48}$ therefore argue for an essential difference in meaning, being concerned with guilt and expiation, $\lambda \dot{\tau} \tau p o v$ with equivalence and compensation, a buying off by means of a price equivalent to that which is redeemed (though it is more commonly used metaphorically with the stress on the fact rather than the price of redemption). $\lambda u^{\prime} \tau$ pov is, therefore, Dr Hooker concludes, an allusion to the idea of redemption in 'DeuteroIsaiah' in general, not to the Servant, of whose work מדה מאל are not used. Two points need to be made in this connection. Firstly, the idea of substitution is not absent from the meaning of 荬: while in Numbers $5: 7,8$ it is a restitution to the one wronged (though presumably, except in cases of actual theft, the restitution of an equivalent), in other cases it signifies the sacrifice presented to make atonement for the sinner; he is

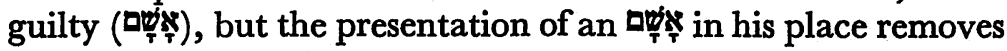
his guilt. ${ }^{49}$ This is hardly distinguishable from the substitution of an equivalent. With reference to Isaiah 53:10, Brown, Driver and Briggs interpret as follows: 'The Messianic servant offers himself as an people, interposing for them as their substitute.'50 If this be

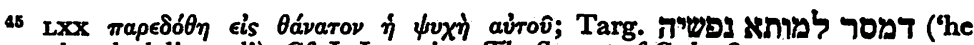
surrendered, delivered'). $C f$. J. Jeremias, The Servant of God, 96 .

46 The Servant of God, 100.

17 Loc. cit., 5-7.

¿8 Op. cit., 76-78.

co See especially Lv. 5:1 7-19. The $a w x$ is in this passage distinguished from the restitution of verses 16 and $23-24$ (EV $6: 4-5)$, which is expressed by the verbs

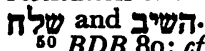

so $B D B$ 80; $c f$. the full treatment, ibid., $79-80$. 
the meaning of behind it, is not far from equivalent to it. ${ }^{51}$ Secondly, Isaiah 53 as a.whole presents the work of the Servant as one of substitution, in that in his suffering and death he bears the sins of the people, resulting in their healing. This idea of substitution is admitted to be central to $\lambda \dot{\tau} \tau p o v$, and is even more obvious in

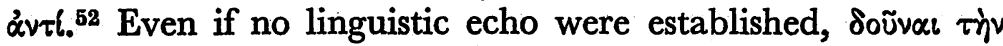

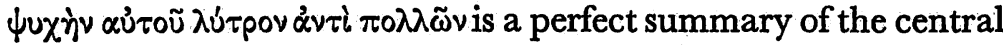
theme of Isaiah 53, that of a vicarious and redeeming death. ${ }^{53}$

The final word, $\pi 0 \lambda \lambda \tilde{\omega} v$, is probably the mos tfrequently noticed verbal echo of Isaiah 53 in this verse. ${ }^{54}$ ברִים is used in Isaiah 53:I I, I2 to describe the beneficiaries of the Servant's sacrifice ( $\left.\operatorname{Lx} \pi 0 \lambda \lambda_{0} \tilde{\zeta}, \pi 0 \lambda \lambda \tilde{\omega} \nu\right) .{ }^{55}$ Jeremias describes it as 'a veritable keyword in Isa. $53^{\prime},{ }^{56}$ and 'Volz remarks that rabbim was a technical term in language relating to the idea of substitution (cf. Dan. ix. 33, xii. 3, Mark x. 45, Rom. v. I9).'57 Most scholars take it for granted that its use in Mark 10:45 is a deliberate echo of Isaiah 53 ; it is hardly the word one would expect unless it had some such purpose..$^{58}$ The other allusions to Isaiah 53 in this verse confirm that this too is a feature drawn from that chapter, where it is no less unexpected a word, and is rendered conspicuous by its repetition. ${ }^{59}$

The cumulative effect of these parallels in word and thought between Mark 10:45 and Isaiah 53 is sufficient to demand a deliberate allusion by Jesus to the role of the Servant as His own. Even those who deny the influence of Isaiah 53 in Jesus'

61 'A perfectly adequate rendering', according to R. H. Fuller, Mission and Achievement, 57. Cf. C. E. B. Cranfield, The Gospel according to Saint Mark, Cambridge University Press (1959) 342; A. J. B. Higgins, Jesus and the Son of Man, 45-46.

${ }_{52}$ V. Taylor, Fesus and His Sacrifice, 103-104 argues for the regular meaning 'instead of', 'in the place of'.

${ }^{83} C f$. V. Taylor, ibid., 102; W. F. Howard, ExpT 50 (1938-9) 109-110; A. Richardson, op. cit., 220-221. Also R. Otto, The Kingdom of God and the Son of Man, ET 2 , Lutterworth Press, London and Redhill (1943) 256-26o.

54 C. T. Craig, Foumal of Religion 24 (1944) 242-243, assumes that it is the only ground for postulating an allusion to Is. 53 in Mk. I0:45 and 14:24!

${ }^{56} C f$. also 52:14. In 53:12 it is also used to designate those among whom the Servant is given an inheritance (or those given to him as an inheritance: so $\mathbf{C}$. $\mathbf{R}$. North, The Second Isaiah, Oxford University Press (1964) 245-246; cf. idem, The Suffering Servant in Deutero-Isaiah, 122, 127).

58 The Servant of God, 95.

57 G. R. North, The Suffering Servant in Deutero-Isaiah, 127.

58 Cf. G. Dalman, Fesus- Feshua, ET, SPCK, London (1929) 171-172.

59 E. Stauffer, Fesus and His Story, ET, SCM, London (1960) 140, and $185-186$ n. 29, finds a further allusion to the clause, 'and for their sins he was stricken'

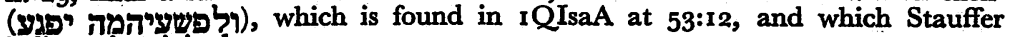
believes is original. 
teaching commonly recognize this, and can only evade its significance by challenging the authenticity of the verse. ${ }^{60}$ Professor Barrett's attempt to undermine the individual constituents of the case (without considering the cumulative effect of the whole, or even the essential parallels of thought underlying the two passages) is the less easy to understand when it is in order to establish instead a dependence on Daniel 7 , with which the only apparent connection is the use of the term 'Son of man', a title which is used by Jesus in such a wide variety of contexts as to belie the suggestion that it must always betray a deliberate allusion to Daniel 7. But to this point we shall have to return.

The fact that the allusion occurs almost incidentally, as an illustration of the true nature of greatness, far from indicating that the redemptive role of the Servant was not in mind (for it is specifically the redemptive aspects of Isaiah 53 to which Jesus alludes), is in fact evidence of how deeply His assumption of that role had penetrated into Jesus' thinking, so that it emerges even in an incidental illustration. 'It is as if Jesus said, "The Son of Man came to fulfil the task of the ebed Yahweh".'"61

\section{(b) Mark I4:24}

A discussion of the authenticity of the words of Jesus at the

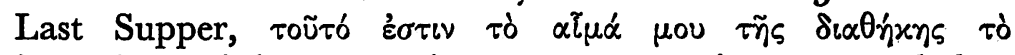

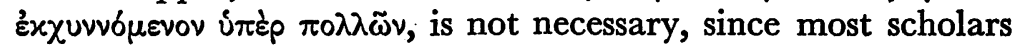
accept that these words, or something very like them, were in fact spoken on that occasion. ${ }^{62}$

The passages of the Old Testament which are most clearly echoed here seem to be the covenant ceremony at Sinai (Ex. 24: $1-8$, especially the phrase 'the blood of the covenant' in verse 8 ) and Jeremiah's prophecy of a new covenant (Jer.

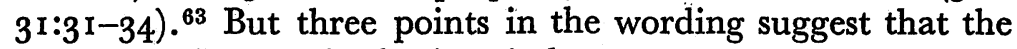
role of the Servant is also in mind.

${ }^{60}$ So e.g. H. Rashdall, op. cit., 32, even though he denies every other use of Is. 53 by Jesus (ibid., $51-52$ ): $C f$. also J. Knox, op. cit., 47; W. G. Kümmel, Promise and Fulfilment ${ }^{3}$, ET, SGM, London (1957) 73. 65.

${ }_{61}$ O. Cullmann, The Christology of the New Testament, ET 2 , SGM, London (1963)

${ }_{62}$ For discussion of this point see especially V. Taylor, Fesus and His Sacrifice, 125-136; J. Jeremias, Eucharistic Words ${ }^{3}$, 168-173, 178-182, 186-203. Cf. also O. Cullmann, Christology, $64-65$.

${ }_{63}$ B. Lindars, $o p$. cit., 132-133, sees Zc. 9:I I as the primary source of such language in the New Testament. His argument depends on the assumption that 
The phrase 'the blood of the covenant' is essentially an allusion to Exodus 24:8. However, the Servant is twice referred to as 'a covenant to the people' (Is. 42:6; 49:8). ${ }^{64}$ Cullmann goes so far as to rank the re-establishment of the covenant as one of the two 'essential characteristics' of the Servant. ${ }^{65}$ There are, of course, many other and more prominent references to the covenant in the Old Testament, and this alone could not constitute an allusion to the Servant, but it does not stand alone.

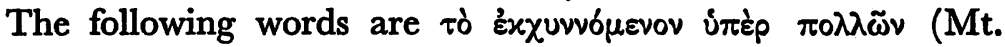

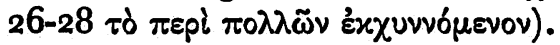

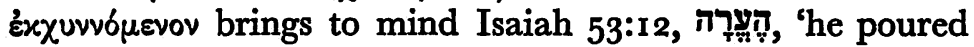
out his soul'.66 This has been taken as the primary reason for postulating an allusion here to the Servant, ${ }^{67}$ but whereas in Isaiah 53:12 העצד is a strange and rather mysterious metaphor,

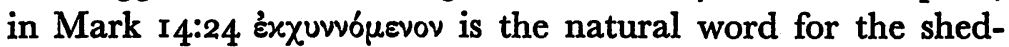
ding of blood, and need not in itself demand an Old Testament background. Like the reference to the covenant, its allusion to the Servant is only clearly established by its conjunction with the more obviously allusive phrase $\dot{\delta} \pi \dot{\rho} \rho(\pi \varepsilon \rho i) \pi 0 \lambda \lambda \tilde{\omega} v_{.}{ }^{68}$

If $\dot{\alpha} v \tau i \pi 0 \lambda \lambda \tilde{\omega} v$ was a strange expression for Jesus to use in Mark 10:45, نं $\pi \dot{\rho} \rho \pi 0 \lambda \lambda \tilde{\omega} \nu$ is no less unexpected here, and the allusion to Isaiah 53 in these words is as widely recognized in this case; for H. E. Tödt the two references reinforce each

the kind of typology involved in a use of Ex. 24:8 here was not found earlier than the Epistle to the Hebrews. This assumption is not borne out by a study of typology in the teaching of Jesus. Moreover, the verbal similarity of Mk. 14:24, to aifá

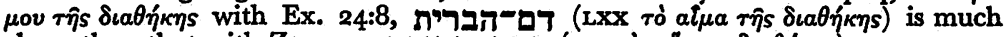

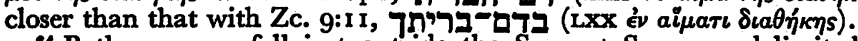

o4 Both passages fall just outside the Servant Songs as delimited by Duhm, but many scholars regard these verses as continuing the Servant theme.

${ }_{65}$ Op. cit., 65. R. H. Fuller, Mission and Achievement, 73, stresses the close connection between the covenant and the Servant idea in these words of Jesus, and concludes, 'What is more likely than that Jesus himself combined Isa. 42. Iff. and Isa. 52.1 $3 \mathrm{ff}$. into a single all-embracing programme for his own mission?' In The Foundations of New Testament Christology (1965) I 18, I53-154, Fuller has not altered his acceptance of the reference of Mk. I0:45 and I4:24 to Is. 53, but now, following Tödt, questions their authenticity.

${ }_{66}$ M. D. Hooker, op. cit., 82, denies the allusion on the ground that the Hiphil of צר means 'to lay bare'. See, however, $B D B$ 788, where for each mood in which the verb occurs the meaning 'pour out' is given as well as 'lay bare'. For the Niphal which $B D B$ characterize as 'pass. of Hiph. 2' (where Is. 53:12 is listed), the meaning 'pour out' is essential in its one occurrence, Is. 32:15. It seems, then, that $B D B$ have good reason for giving the meaning in Is. 53:12 as 'pour out'. The $\mathrm{LXX}$ and Targ. versions (for which see above, n. 45) do not help us to determine the metaphor of the Hebrew.

${ }^{87}$ So R. H. Gundry, op. cit., 70.

${ }^{68}$ Cf. A. J. B. Higgins, The Lord's Supper in the New Testament, SCM, London (1952) $32 ;$ R. H. Fuller, Mission and Achievement, 75. 
other. ${ }^{69}$ While $i \pi \varepsilon p$ (and still more the Matthean $\pi \varepsilon p i$ ) is not so clearly substitutionary as $\alpha \nu \tau i$, it is a very appropriate word for the vicarious death of the Servant. So not only the word $\pi 0 \lambda \lambda \tilde{\omega} v$, but the whole idea of 'dying on behalf of', which is central to Mark 14:24, renders an allusion to the Servant theme virtually certain.

The connection of these words with the covenant theme is significant. In Isaiah 42-53 Yahweh makes His Servant a covenant to the people, and this involves his vicarious death for their redemption. ${ }^{70}$ Jesus' words at the Last Supper, whose purpose is to explain how His coming death is to benefit them, allude not only to the covenant theme (in Ex. 24:8 and Jer. 31:3I), but also to the work of the Servant in Isaiah 53. His work is to re-establish the broken covenant, but this can only be done by fulfilling the role of the Servant in his vicarious death. To make this point, Jesus chooses words from Isaiah 53 which are as deeply imbued as any with the redemptive significance of that death, in that they highlight its vicarious nature.

Thus here, if anywhere, we have a deliberate theological explanation by Jesus of the necessity for His death, and it is not only drawn from Isaiah 53 , but specifically refers to the vicarious and redemptive suffering which is the central theme of that chapter. ${ }^{71}$

\section{Other Possible Allusions}

We do not here intend to indulge in that favourite pastime of some scholars which consists in postulating allusions to the Old Testament in every chance verbal or conceptual similarity. We mention here only two suggested allusions to the Servant in the words of Jesus where there is some reason in the context of the saying for seeing some significance in the verbal echo, and one further suggested echo which has commended itself to many scholars as an intentional allusion. ${ }^{72}$

${ }^{89}$ Op. cit., 205 n. 1. For details see above p. 36, all of which applies equally here. J. Jeremias, Eucharistic Words', 226-231, assumes the allusion to Is. 53 as self-evident; $c f$. also R. V. G. Tasker, The Old Testament in the New Testaments, SCM, London (r954) 21 .

${ }_{70}$ G. Dalman, op. cit., 170 , points out that here only in the Old Testament is there a relationship between the covenant and the death of its mediator.

71 Even C. F. D. Moule (loc, cit., 51), while denying a verbal parallel, admits that these words are 'close in theme to that chapter'.

${ }^{72}$ See also below pp. 44, 45 for suggested verbal echoes in the passion predictions. 
(a) Mark 9:12

We shall consider Jesus' predictions of His suffering in general terms below. This particular saying must, however, be singled out because, in addition to the similarity of the thought to that of Isaiah 53 , the word $\varepsilon \xi o v \delta \varepsilon v \eta \theta \tilde{n}$ is frequently regarded as a

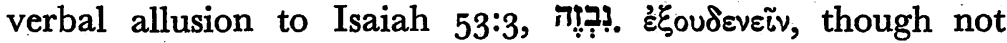
used in this verse by the $\mathbf{L x x}$, was a standard translation of

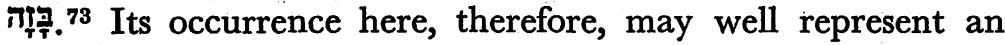
Aramaic word which alluded to Isaiah 53:3, where used. Without the support of the context, this possible verbal connection could not be advanced as ground for postulating an intended allusion. But in fact the context, in which Jesus is declaring that Scripture foretells His suffering and rejection, might well lead us to assume the influence of Isaiah 53 even without such a verbal hint. Our discussion of such predictions below will give reasons for tracing Jesus' authority for them to Isaiah 53; this verse merely adds a verbal confirmation to that argument. It seems then that here, in a deliberate statement of the appointed pattern of His mission, Jesus refers to the suffering and rejection of the Servant.

\section{(b) Matthew 3:15}

It is almost universally recognized that the heavenly voice at

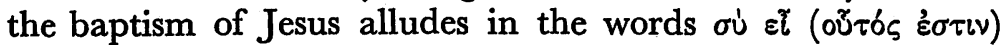

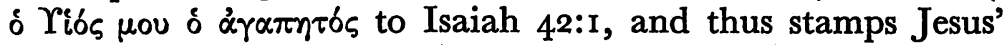
mission at its outset as that of the Servant. ${ }^{74}$ This pronouncement, not being strictly a saying of Jesus, falls outside our scope, but its influence on His subsequent thinking cannot be ignored. This fact lends weight to the suggestion that a reference to the work of the Servant is also implied in Jesus' own enigmatic explanation of the necessity for His participation in a baptism

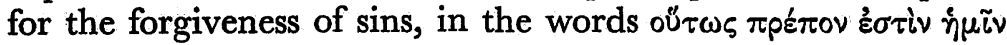
$\pi \lambda \eta p \tilde{\omega} \sigma \alpha \iota \pi \tilde{\alpha} \sigma \alpha \nu \delta \iota x \alpha \iota \sigma^{\prime} v \eta \eta v$. While some scholars see here a general reference to Jesus' identification of Himself with

78 For details of the various Greek translations of this and other occurrences of בזה see G. E. B. Cranfield, op. cit., 298.

${ }_{74}$ Mk. I:I I and parallels. See e.g. G. H. Dodd, According to the Scriptures, Nisbet, London (1952) 89; J. Jeremias, The Servant of God, 81-83. M. D. Hooker, op. cit., 70-73, disputes the allusion on the ground of its disagreement with the $\mathrm{xxx}$ version of Is. 42:I. It is, however, gratuitous to assume that the saying originated in Greek; and in any case Mt. 12:18 is evidence of a recognized Greek translation divergent from the $\mathrm{Lxx}$, and very close to Mk I:I I. 
sinful men for their redemption, ${ }^{75}$ Cullmann, Robinson, and others have tied the allusion down to the figure of the Servant. ${ }^{76}$ The particular point of reference would be Isaiah 53: I I, 'By his knowledge shall the righteous one, my servant, make many to

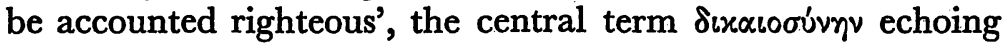

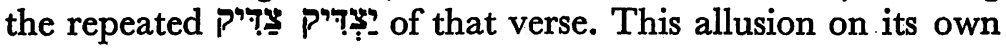
is not sufficiently clear, but at least we may be sure that Jesus, at the time of His baptism, was confronted with a delineation of His mission in terms of Isaiah 42:I. It is reasonable to infer that the figure of the Servant thereafter influenced His selfestimation.

\section{(c) Luke II:22}

Some commentators find in the picture of the i $\sigma \chi \chi p o ́ \tau \varepsilon p o s$

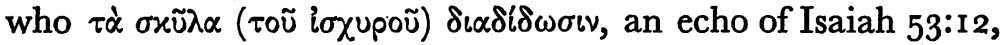

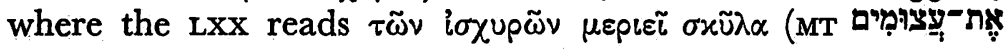
must mean 'with the strong'). ${ }^{77} \mathrm{~K}$. H. Rengstorf ${ }^{78}$ expounds the verse in terms of Jesus' conquest of the devil by His death as the Servant, but there is no mention of the suffering or death of Jesus in the context in Luke. In the absence of a clear conceptual parallel it would be hazardous to draw any conclusions from the verbal similarity, which is in fact hardly impressive. ${ }^{79}$

${ }^{75}$ See e.g. G. Barth, in G. Bornkamm, G. Barth, and H. J. Held, Tradition and Interpretation in Matthew, ET, SCM, London (1963) 138-141, following G. Bornkamm. H. Ljungman, in his massive treatment of this verse, Das Gesetz Erfillen: Matth. 5, I7ff. und 3, I5 untersucht (Lunds Universitets Arsskrift, NF Avd I, Bd 50, Nr 6; Lund (1954)), notices the suggested connection with Is. 53 (ibid., IOI-102), but concludes that the saying refers to Jesus' death and its beneficial effects, without any single Old Testament reference.

${ }^{76}$ O. Cullmann, Baptism in the New Testament, ET, SCM, London (1950) 16-19; idem, Christology, 67; J. A. T. Robinson, $S \mathcal{F} 6$ (1953) 261. Cf. also J. Schniewind, Das Evangelium nach Matthäus ${ }^{8}$, Vandenhoeck \& Ruprecht, Göttingen (1956) 27; and most fully J. Denney, The Death of Christ, new edition ed. R. V. G. Tasker, Tyndale Press, London (1951) $21-23$. J. H. Crehan in A Catholic Dictionary of Theology, vol. 2, Nelson, London (1967) 34, accepting this interpretation of Mt. $3: 15$, adds, ' $C$. $R$. North has revived, with wide agreement, this old interpretation of Christ's words.' I have been unable to trace the relevant work of North.

${ }^{7}$ So J. M. Creed, op. cit., 16r; W. Grundmann, Das Evangelium nach Lukas', Evangelische Verlagsanstalt, Berlin (I96r) 239; W. Manson, The Gospel of Luke, Hodder and Stoughton, London (1930) 140; A. Plummer, The Gospel according to S. Luke $e^{4}$ T. \& T. Clark, Edinburgh (1901) 303. Cf. also B. Lindars, op. cit., 84-85.

${ }_{78}$ Das Evangelium nach Lukas 8 , Vandenhoeck \& Ruprecht, Göttingen (I958) 149. Cf. also A. R. C. Leaney, The Gospel according to St. Luke, A. \& C. Black, London (1958) 190.

${ }_{79}$ The words are common ones, and the action of dividing spoil is a regular accompaniment of victory (Gn. 49:27; Ex. 15:9; Jos. 22:8; Jdg. 5:30; I Sa. $30: 22-26$, etc.); besides, the 'strong' are the recipients of the spoil in the Hebrew. 
Thus, of the three suggested allusions examined in this section, two, Mark 9:12 and Matthew 3:15, in both of which the Gospel context reinforces the reference to the Servant that is suggested by the wording, may be taken into account, but the third, Luke I I:22, where the echo is purely verbal, without contextual support, must be regarded with suspicion.

\section{B. JESUS' USE OF ISAIAH 6r: $\mathrm{r}-3$}

Whatever may be thought of the Servant of Yahweh, there can be little doubt that the Lord's Anointed as depicted in Isaiah 6r: $1-3$ did figure in Jesus' estimation of His own mission. It was of this passage that Jesus declared in the synagogue at Nazareth,

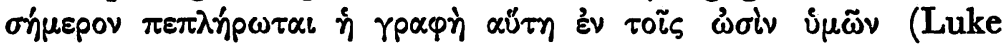
4:I6-2I). When John the Baptist sent to enquire whether $\mathrm{He}$

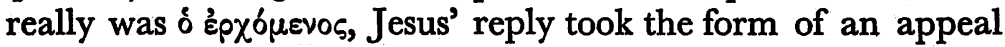
to His literal fulfilment of Isaiah $35: 5-6$ and Isaiah 6I:I (Matthew II:4-5). A further allusion is probably to be seen in Matthew 5:3-4, both in the word $\pi \tau \omega x$ of (Isaiah 6r:I Q LXX

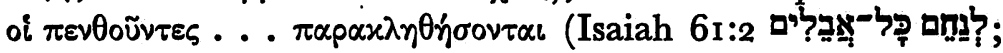

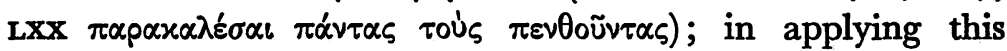
description of the work of the Messiah to the blessedness of His own disciples, Jesus would seem again to imply the fulfilment of Isaiah 6r: $1-3$ in His own mission.

$\mathrm{J}$. W. Bowman ${ }^{80}$ bases his case for Jesus' self-identification with the Servant on His clear application of Isaiah $6 \mathrm{I}$ to His mission. This is to go beyond the evidence, ${ }^{81}$ for Isaiah $6 \mathrm{I}$ is not, explicitly at least, a Servant Song, and it is not certain that Jesus saw any connection between the Lord's Anointed here and the suffering Servant of Isaiah $53 .{ }^{82}$ There are, however, close similarities between the mission of Isaiah $61: 1-3$ and that of the Servant in Isaiah $42: 1-7,{ }^{83}$ sufficient to lead some

Lindars' appeal (op. cit., $85 \mathrm{n}$. I) to the $\mathrm{Lxx}$ is hardly convincing in a passage where the $\mathrm{LXX}$ is not conspicuous for its fidelity to the Hebrew.

${ }^{80}$ The Intention of Jesus, SGM, London (1945) 130-1 31 ; cf. ibid., 103.

81 Cf. M. D. Hooker, op. cit., 19 .

82 His allusions to Is. 61 combine it with Is. 35 (Mt. $11: 5$ ) and Is. $5^{8}$ (Lk. 4:18), not with Is. 53 or the other Servant Songs.

${ }_{88}$ See W. W. Cannon, ZAW n.F. 6 (rg29) 287-288; C. H. Dodd, op. cit., 94. Both the Lord's Anointed in Is. 6I and the Servant in Is. 42 are endued with the Spirit, bring prisoners out of darkness, and open blind eyes. On the last point a

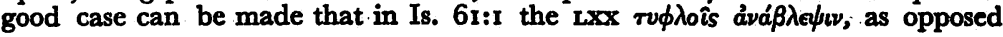


scholars to believe that both passages are meant to refer to the same messianic figure. ${ }^{84}$ Certainly, Jesus can hardly have failed to notice the similarity of these two figures, which stand so close together in the same book of the Old Testament, ${ }^{85}$ and the fact that He so emphatically applied the one to His own work must therefore strongly suggest, though it cannot prove, that He would have regarded the other as no less applicable. While, therefore, His use of Isaiah 6r cannot prove our case, it provides important confirmatory evidence.

\section{THE PASSION PREDICTIONS}

In section $\mathrm{A}$ above we restricted our attention to sayings where the wording showed signs of being a deliberate echo of a Servant passage in Isaiah. There is also, however, a large body of sayings which predict, sometimes in some detail, the impending suffering and death of Jesus. ${ }^{86}$ While the authenticity of

to the normal translation represented by Rsv, 'the opening of the prison to those who are bound', represents the true sense of the Hebrew

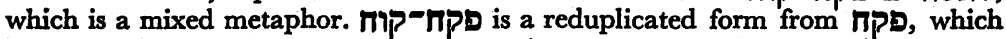
is invariably used of the opening of eyes (except the transferred use in Is. 42:20 for opening ears). רורא, on the other hand, as definitely means a 'prisoner', 'one bound'. Thus either we must see from dark prison' $(B D B)$, or we must take 7וסא as figurative for 'blind' (i.e., one whose eyes are bound). Either figure would be unique, and there is no clear reason for preferring the former. The $\mathrm{Lxx}$ has opted for the latter alternative, while the Targ. has a similar mixed metaphor. See further F. Delitzsch, Biblical Commentary on the Prophecies of Isaiah4, ET, T. \& T. Clark, Edinburgh (189o) vol. 2, 395-397.

84 So F. F. Bruce, NTS 2 (1955-56) 176. Cf. G. G. Montefiore, The Synoptic Gospels', Macmillan, London (1927) vol. 2, 396, followed by W. Manson, The Gospel of Luke, 41. Is. 61: I-3 was regarded as a fifth Servant Song by e.g. F. Delitzsch, op. cit., vol. 2, 395-396; C. C. Torrey, The Second Isaiah, T. \& T. Glark, Edinburgh (1928) 142, 452-453; W. W. Cannon, loc. cit. Modern scholarship has not endorsed this view: see especially J. S. Van der Ploeg, Les Chants du Serviteur de Fahve, Gabalda, Paris (1936) 201-204; G. R. North, The Suffering Servant in DeuteroIsaiah, 137-138. North does, however, regard these verses as 'belonging to the same complex of passages' as Is. 42 and 53 (ibid., 25). M. D. Hooker, op. cit., 85, accepts that the two figures are likely to have been connected in Jesus' time. The suggestion that the figure in Is. 61:1-3 is the prophet himself, and not a strictly messianic figure (so J. S. Van der Ploeg, op. cit., 204-205) is unlikely: the passage bears a much greater resemblance to the Servant Songs than to any place where the prophet speaks of himself, both in the figure described (see above n. 83), and in the wording, in that nowhere in Is. 40-66 is the first person used by the prophet in describing his own work, but it is used both in Is. 61, and in the second and third Servant Songs.

${ }^{85}$ Whatever one's view of the authorship of Isaiah, it must surely be assumed that Jesus was innocent of 'Deutero-' and 'Trito-Isaiah'!

${ }_{86}$ In addition to the three formal announcements of the passion in Mk. 8:31; 9:31 ; 10:33-34 and parallels, the following passages also show Jesus' consciousness that it was inevitable: Mk 2:20; 9:12; 10:38; 12:Iff.; 14:8, 21, 22-23, 25, 49; Mt. 
some of these sayings has been questioned, it can hardly be disputed that Jesus did in fact predict His suffering and death; the predictions are too numerous and too varied to be lightly discounted, and many display clear signs of their authenticity in both their language and their content. ${ }^{87}$ Our concern here is not with any individual saying, but with the simple fact of Jesus' expectation of His suffering, and this may be safely assumed.

In some of these sayings there is simply a prediction of what will happen, but in others the indicative gives way to an imperative: He must suffer. ( $\delta \varepsilon \tilde{\imath}$ is used in Mk. 8:31; Mt. 26:54;

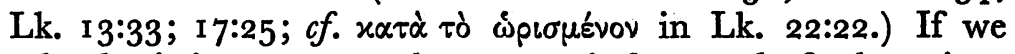
ask why it is necessary, the answer is frequently forthcoming: it is written. ${ }^{88}$ Thus we find the simple $\gamma^{\varepsilon} \gamma p \alpha \pi \tau \alpha \iota$ (Mk. 9:12;

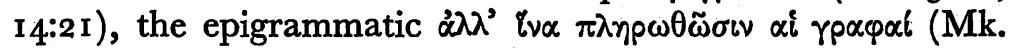
I4:49), and the more formal and emphatic assertions of Matthew 26:54 and Luke 18:31.89

In none of these predictions, however, is a specific Old Testament passage mentioned. Attempts have, accordingly, been made to discover the passage in mind by studying the actual wording of the sayings. Echoes of Isaiah 53 have been traced not only in the $\varepsilon \xi \xi_{0} \delta \varepsilon v \eta \tilde{n}$ of Mark 9:12,90 but also in the use of $\pi \alpha \rho \alpha \delta \delta \delta \circ \sigma \alpha \iota$ in the formal predictions of Mark 9:3I; I0:33 and parallels, and in Mark 14:21.91 However, of the two uses of $\pi \propto p \varepsilon \delta 6 \theta \eta$ in the Lxx of Isaiah 53:12, the first is a

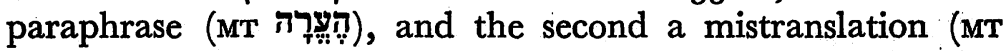
פִ

26:54; Lk. 9:31; 12:50; 13:32-33; 1 7:25. These are all general predictions, without reference to any one Old Testament passage, such as is found in Mk. 10:45; $14: 24,27$, etc.

${ }_{87} C f$. J. Jeremias, The Servant of God, $103-106$ for details. This evidence is more convincing than such dogmatic generalizations as the words of $\mathbf{H}$. M. Teeple, $\mathcal{F B L} 84$ ( 1965 ) 227, on the suffering Son of man sayings: 'This group of logia displays such detailed knowledge of the Passion story that the sayings simply must have originated vaticinia ex eventu.' (sic) The circumstances of Jesus' life and ministry must alone have made His passion a clear probability: see J. Jeremias, ibid., ror-103; E. Stauffer, op. cit., 139 .

$88 \mathrm{Cf}$. H. E. Tödt, op. cit., IgI : 'The reason for the "must" of the Son of Man's suffering is God's will as revealed in Scripture.'

${ }^{80} \mathrm{Cf}$. also Jesus' strong emphasis on the scriptural necessity of His suffering after the event: Lk. 24:25-27; 24:44-46.

${ }^{90}$ See above p. 40.

91 So e.g. B. Lindars, op. cit., 80-81; J. Jeremias, The Servant of God, 96-97, 99, 105. Cf. contra F. J. F. Jackson and K. Lake, op. cit., vol. $\mathrm{x}, 386 ; \mathrm{M}$. D. Hooker, op. cit., 94-95; and most fully $\mathrm{H}$. E. Tödt, op. cit., 159-16r.

${ }_{92}$ See above $n$. 59 for the variant reading at Qumran, which would be closer to the LXX. 
underlying this word. ${ }^{93}$ Nor is an allusion to the Lxx likely, since in the three Marcan passages $\pi \alpha p \alpha \delta(\delta \circ \sigma \theta \alpha \iota$ means 'to be betrayed, handed over (to his enemies)', a quite natural meaning of the word, ${ }^{94}$ and different from that in Isaiah 53:12, where in each case it means 'to be given up (to death)'. A further suggested allusion to Isaiah 53:5 in the word $\mu \alpha \sigma \tau \gamma$ -

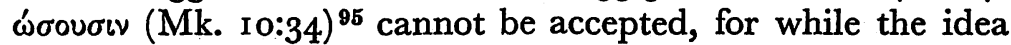
is clearly the same, there is no verbal similarity either to the Hebrew ใח allusion to any Old Testament passage in these predictions is

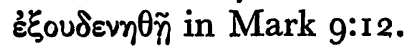

Yet there is a strong consensus of opinion that the major, if not the only, source of these predictions was Isaiah 53. The reason for this lies not only, or even primarily, in the allusions to Isaiah 53 which we have examined in Mark 9:12; 10:45; 14:24; Luke 22:37, but in the close correspondence in content, even if not in words, between Jesus' predictions of mocking, suffering, and death, and the picture in Isaiah 53. Even Dr Hooker, whose aim is to minimize the influence of Isaiah 53 on the teaching of Jesus, admits this. ${ }^{96}$

But, granted that Isaiah 53 was an influence in forming Jesus' conviction that He must suffer, were there not other, perhaps weightier, influences? Dr Hooker writes, 'The portrait of Isa. 52-3, however, is only one element in the whole pattern of suffering and exaltation which marks all Deutero-Isaiah's thought, and which runs through Jewish literature, from ritual psalms to apocalyptic visions.' ${ }^{97}$ It is, of course, true that 'suffering and exaltation' play a large part in the Old Testament, and indeed in the history of Israel. But what is required to explain Jesus' expectation of suffering is prediction of the suffering of the Messiah, and here the field is much more restricted. Certainly Jesus saw and applied to Himself such an idea in the latter part of Zechariah, especially in Zechariah

93 Or to the Aramaic, at least as represented by Targ. Jonathan. Jeremias sees an echo of Targ. Is. 53:5b רonא (The Servant of God, 99), but the subject in the Targ. is the sanctuary, not the Servant.

${ }_{94} C f$. F. J. F. Jackson and K. Lake, op. cit., vol. I, 386. R. H. Fuller, Mission and Achievement, 58, regards the word as derived not from Is. 53 but 'from common secular usage'.

${ }^{95}$ B. Lindars, op. cit., 81.

os Op. cit., 95: 'As a general summary, however, the predictions do correspond broadly with the picture of Isa. 53. '

${ }^{27}$ Ibid., 162. 
13:7, which He quoted in Mark $14: 27,98$ and it is probable that He saw His own suffering foreshadowed in that of some of the Psalmists. ${ }^{99}$ The suggestion that $\mathrm{He}$ derived His expectation of suffering from Daniel 7 will be considered shortly. But it may be stated without fear of contradiction that not one of these passages, nor any other which might be adduced, so clearly stresses suffering as the essential mission of the Messiah as does Isaiah 53; nowhere else is suffering of such central importance, or so strikingly presented. Isaiah 53 , poetic as it is, gives a systematic exposition of the nature, necessity and purpose of the suffering of the Messiah, which is true of no other passage of the Old Testament. When we add to this the close correspondence between Jesus' predictions of His suffering and the pattern laid down by Isaiah 53, we must, on the ground of these general predictions alone, regard Isaiah 53 as the major source of Jesus' conviction that $\mathrm{He}$, as Messiah, must suffer. ${ }^{100}$ The several clear cases of His use of Isaiah 53 in just this way which we have considered above give to this conclusion at least a very high degree of probability.

We have, however, mentioned above that those who minimize the role of Isaiah 53 in the thinking of Jesus find the source of His expectation of suffering rather in Daniel 7. In many of the predictions of His suffering, Jesus refers to Himself as

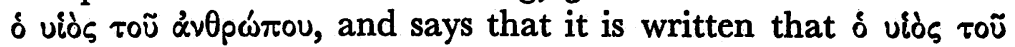

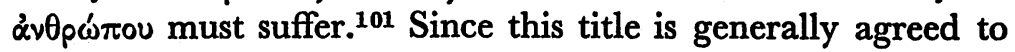
be derived mainly, if not solely, from Daniel 7:13, it is argued that Daniel 7 is also the source of the prediction of suffering. The fullest exposition of this argument is that by G. K. Barrett. ${ }^{102}$ Professor Barrett discusses the ideas of martyrdom in Jewish apocalyptic, and outlines the development of the concept of vicarious suffering in post-Old Testament times (quoting passages from 2 Maccabees and 4 Maccabees, and some rabbinic parallels). He then goes on to argue for the same idea in Daniel 7. Observing that in Daniel 7 the 'saints of the Most

${ }^{98} C f$. also the use of Zc. 12:10ff. in Mt. 24:30. For the influence of Zc. 9-14 as a whole on Christian understanding of the passion see F. F. Bruce, BfRL 43 (1960-6r) 336-353.

90 See especially His use of Pss. 22 (Mk. 15:34); 4 I (Mk. 14:18); 42-43 (Mk. 14:34); and 118 (Mk. $12: 10-11$; Mt. 23:39). Other Psalms which might have led to the same expectation include $31,34,69$, 109. Cf. B. Lindars, op. cit., 88 and the following discussion.

100 Cf. R. Otto, op. cit., 244-255.

101 See Mk. 8:31; 9:12; 9:31; 10:33; 10:45; 14:21; Lk. 17:24-25.

${ }^{102}$ Loc. cit., 8-15. 
High' had been subjected to oppression before the appearance of the Son of man (Dn. 7:21, 25), and that the Son of man represents them, he transfers their suffering and martyrdom to the Son of $\operatorname{man} ;^{103}$ as, therefore, his capacity is a representative one, his suffering is on their behalf; 'he gives his life as $\lambda \dot{v} \tau$ pov

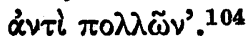

This construction is exposed to at least three serious objections, the cumulative effect of which is surely fatal:

(a) In Daniel 7 the Son of man is a figure for the saints not in their suffering, but in their vindication and power. It is neither stated nor implied that the Son of man suffers; he is throughout a victorious person, and it was as such that both Jewish apocalyptic and the rabbinic writers unanimously regarded him. $\mathrm{He}$ is, in the words of $\mathrm{H}$. $\mathrm{H}$. Rowley, 'a figure for the saints only after they are invested with power' ${ }^{105}$

(b) Even if it were legitimate to infer the suffering of the Son of man from that of the people he represents, it is not legitimate to suggest that he suffers on their behalf. He is never set over against them as an individual against a community. He is the people, represented in a visionary form. His triumph is their triumph, and his suffering, if it can be postulated, is their suffering. He cannot be said to suffer in their place. He is not a separate figure with a separate history; his experiences are theirs. Thus the very identity between the saints and the Son of man which is used to justify the ascription of suffering to the latter, inevitably rules out the idea of vicarious suffering. Whatever may have been evolved in later apocalyptic or rabbinic thought, Daniel 7 has no place for this idea.

(c) At two points the actual allusions by Jesus to Daniel 7 run counter to Professor Barrett's theory. There are seven such

${ }^{103}$ Cf. C. F. D. Moule, loc. cit., 45, on Dn. 7:21-22: “"The Son of Man" already means "the representative of God's chosen people, destined through suffering to be exalted". Cf. also W. D. Davies, Paul and Rabbinic Judaism", SPCK, London (1955) 280 n. I; M. D. Hooker, op. cit., 160.

106 Loc. cit., 14 .

105 H. H. Rowley, The Servant of the Lord, Lutterworth Press, London (1952) 62, n. 2. Cf. J. W. Doeve, Jewish Hermeneutics in the Synoptic Gospels and Acts, Van Gorcum, Assen (1954) 131: 'Suffering is foreign to the figure in Daniel VII.' For the use of this figure in apocalyptic see S. Mowinckel, He That Cometh, ET, Blackwell, Oxford (1956) 410-415. For the rabbinic use see especially Sanh. 98a, where the figure of $\mathrm{Dn}$. 7:1 3 is set in contrast with the lowly Messiah of Zc. 9:9. See also e.g. Midr. Ps. 21 I5 (on v. 7), Num. R. I3:14, and other uses listed by $S B$ I 957 . In all the passages cited by $S B$ (II 273-299) as enshrining the idea of a suffering and a dying Messiah, there is no reference to Dn. 7. In Midr. Wayyosha $a^{6}$ n. 7:13-14 is applied to the victorious Messiah ben David in contrast to the dying Messiah ben Joseph (SB III 639). 
allusions, of varying degrees of probability, in the Synoptic Gospels, viz. Mark 8:38; 13:26; 14:62; Matthew 10:23; 19:28; $25: 31 ; 28: 18 .{ }^{106}$. The first point to be noted about these seven allusions is that in every case the reference, whether verbal or conceptual, is to verses $13-14$, the picture of the triumphant exaltation of the Son of man; there is no allusion to the suffering and oppression of the saints, still less to any such suffering of the Son of man. The second point is that these seven allusions without exception apply Daniel 7 to the period of Jesus' triumph after the resurrection, whether in His immediate assumption of dominion (see especially Matthew 28:18), or in its future manifestation in judgment; the chapter is never applied to His earthly life and work. ${ }^{107}$ The suggestion that Jesus' predictions of His earthly suffering and death were derived from Daniel 7 thus stands in striking contrast with His actual application of that chapter consistently to the glory and power which succeeded His resurrection.

To these three objections must be added the sheer improbability of the view that it was from Daniel 7 , where the very idea of messianic suffering has only in recent years been detected,

${ }^{108}$ We do not regard the term 'Son of man' alone as evidence of an intended allusion to Dn. 7, for the following reasons. (a) The term 'Son of man' does not seem to have been current at the time as a recognized title for the figure in Dn. 7:13. In non-Christian Jewish literature up to $\mathrm{AD} 300$ the only occurrences of this title as such are in the Similitudes of Enoch, possibly the Targ. Ps. 80:18 (EVV

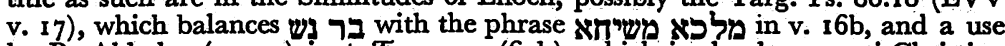
by $R$. Abbahu (c. 300) in $p$ Taan. 2:I $(65 \mathrm{~b})$, which is clearly an anti-Christian polemic, and therefore derived from Christian usage. See $S B$ I 958-959 for details. It is illegitimate to generalize from the usage in the Similitudes of Enoch, whose wide influence, and even pre-Christian date, are now disputed, particularly since their failure to appear among the Enochic literature in Qumran Cave 4. (See especially J. T. Milik, Ten Years of Discovery in the Wilderness of Judaea, ET, SCM, London (1959) 33-34; contra A. Dupont-Sommer, The Essene Writings from Qumran ${ }^{2}$, ET, Blackwell, Oxford (I96r) 299-300; also R. H. Fuller, Foundations, 37-38; G. H. P. Thompson, ExpT 72 (1960-6I) 125. Cf. C. H. Dodd, op. cit., I I6-1 I7; $S B$ I 486, 957.) Yet Dn. 7:13-14 is during this period frequently applied to the Messiah, and in fact this is the only use of these verses known before about AD 300. (For details see n. 105, and references given there.) The central figure of these verses was, therefore, known not as 'the Son of man', but more clumsily by such phrases as 'the one who came with the clouds of heaven', or ryjy (See Targ. I Ch. 3:24, with Tanh. B Toledoth $\$ 20$ (7ob), in SB I 67). (b) The use of the term 'Son of man' by Jesus is too varied to restrict its reference always to Dn. 7:13, even though that verse is the source from which $\mathrm{He}$ derived the title. It became His chosen title to describe His Messiahship in all its aspects, and is associated with ideas which find no place in Dn. 7. We therefore postulate an allusion to Dn. 7 only where the wording and the thought suggest that that chapter is in mind, whether the term 'Son of man' is present or not.

${ }_{107}$ The 'coming of the Son of man' in Mk. 8:38 and Mt. 10:23 has been interpreted of the transfiguration or some other episode in the life of Jesus, but such interpretations depend more on apologetic considerations than on exegetical probability. 
that Jesus derived His conviction that He must suffer, and not from Isaiah 53, which presents the vicarious suffering of the Servant of Yahweh so clearly and vividly that Ghristian exegesis from the days of the New Testament has agreed in interpreting it as a prediction of the suffering of Jesus. When further we observe that Jesus did in fact apply Isaiah 53 to His coming passion in Luke 22:37; Mark 10:45; and Mark 14:24 (in the last two cases with the primary reference to the idea of vicarious suffering), and possibly alluded to it also in Mark 9:12 and Matthew 3:I5 (and notice also the inevitable effect of the pronouncement of Mark I:I I on His subsequent thinking), it seems rather odd that a source for His passion-predictions in general should be sought in a passage where suffering is not, at least explicitly, predicated of the Son of man, while no account is taken of the clearest statement in the Old Testament that the Christ must suffer. ${ }^{108}$

\section{GONCLUSIONS}

Those who reject the view that Jesus interpreted His mission in large measure as that of the Servant, ask us to show four things: (I) that $\mathrm{He}$ referred to this figure at all; (2) that these allusions were intended to convey that $\mathrm{He}$ was the Servant, and were not mere catch-phrases or generalities; (3) that $\mathrm{He}$ referred in particular to the suffering, which was the distinctive mark of the Servant; (4) that He saw this suffering, as Isaiah 53 depicts it, as vicarious and redemptive. We are now in a position to attempt an answer to this fourfold challenge.

(I) The specific allusions to the Servant figure which we have surveyed are in fact more numerous than Jesus' allusions to any other Old Testament figure except the Son of man of Daniel 7. We discovered one formal quotation, two clear allusions, and two other possible verbal allusions. In addition there is the considerable body of the passion-predictions, of which we have found Isaiah 53 to be the most likely source. When we add that Jesus' ministry was inaugurated by a heavenly voice which identified Him as the Servant, it is hard to believe that this figure was not a major constituent in His view of His mission.

(2) That these were not mere catch-phrases or generalities ${ }^{108} C f$. A. J. B. Higgins, Fesus and the Son of Man, 205; also V. Taylor, Fesus and His Sacrifice, 9o; A Richardson, op. cit., 135-1 36 . 
is indicated by the formula of Luke 22:37, with its affirmation that Isaiah 53:12 was written about $\mathrm{Him}$, and that $\mathrm{He}$ must fulfil it, ${ }^{109}$ and by the similar formulae introducing several of His predictions of His suffering, to the effect that these things must happen to Him. There is no suggestion that these are general duties or experiences of all true servants of God; He, and $\mathrm{He}$ alone, must suffer these things, because it is written of Him. Even where there is no formula, the sense of purpose is marked: 'the Son of man came to serve and to give his life.' The suggestion is that the Servant figure provided a 'blueprint' for His ministry, which He must follow. It is significant that an allusion to the Servant concept is found embedded in one of Jesus' most solemn sayings about the nature of His work, the Words of Institution at the Last Supper, hardly an occasion for catch-phrases whose implications were not intended to be taken seriously.

(3) It would, of course, have been very difficult for Jesus to see His mission as that of the Servant, and yet to ignore the suffering which is the most prominent and revolutionary aspect of that figure. In fact, every reference to the Servant which we have noted, with one exception, is in a context of the suffering of Jesus, either in a direct prediction of His suffering, or, in the case of Luke 22:37, in a reference to a fundamental aspect of that suffering, spoken at a time when suffering filled the horizon. The one exception is Matthew 3:15, and even here the identification with sinners 'to fulfil all righteousness' may be expected to involve suffering. All the specific references (with the exception of the voice from heaven in Mark I:I I) are to Isaiah 53, the passage where the suffering of the Servant comes to the fore, and are to parts of that chapter where suffering and death are emphasized (especially to verses ro and 12).110

(4) The theological significance of the suffering of the Servant is not explicit in every allusion by Jesus; many are simple predictions of the fact that He must suffer. The three clearest references to the Servant, however, all go beyond the mere fact of suffering to its redemptive significance. Luke 22:37 was not, it is true, spoken in a context of theological explana-

109 See above pp. 31, 32.

110 This fact contrasts strongly with Jesus' use of Dn. 7, where there is no explicit allusion to suffering. Thus, while Is. 53 meets this criterion set up by M.D. Hooker and the others for the source of Jesus' conviction that He must suffer, Dn. 7 fails to meet it. 
tion; but the words chosen emphasize that identification of the Sinless with sinners which was the essence of the Servant's substitutionary suffering, and the fact that this suffering was then so imminent suggests that Jesus was not unaware of the theological implication of the words. ${ }^{111}$ (There is probably a similar implication in Matthew 3:15, with its mention of identification with sinners as a means to 'righteousness'.) Mark I0:45 is unambiguously redemptive in tone; $\lambda u ́ \tau p o v$ áv $\tau i$ $\pi 0 \lambda \lambda \tilde{\omega} \nu$ is an allusion to, and summary of, the part of Isaiah 53 which most explicitly portrays the Servant as dying in the place of sinners to achieve their salvation. ${ }^{112}$ Further, the point of the phrase in its context is to provide an illustration of true service; Jesus' death is therefore not viewed simply in itself, but in the light of the benefit it brings to others. Finally we need not repeat here what we said above $\mathrm{e}^{113}$ about the theological significance of Mark $14: 24$; it is for their benefit that His blood is to be shed. Thus even if we accept the contention that a theological purpose or understanding can only be assumed where it is explicit in the words of Jesus, the sayings considered provide us with sufficient evidence. We would, however, question the assumption that it would be possible for Jesus consciously to accept the role of the Servant, and yet to be unaware of the teaching of Isaiah 53 on the meaning of the Servant's suffering. To accept the role of the Servant is ipso facto to accept a vocation of suffering for the redemption of others, and this Jesus did.

We conclude, therefore, that Jesus saw His mission as that of the Servant of Yahweh, that He predicted that in fulfilment of that role $\mathrm{He}$ must suffer and die, and that $\mathrm{He}$ regarded $\mathrm{His}$ suffering and death as, like that of the Servant, vicarious and redemptive. ${ }^{114}$

Space forbids a lengthy discussion of the Christological implications of this conclusion, nor is this our intention in this paper. Such discussions have been frequently published; indeed some such discussion is central to any adequate work on the Christology of the New Testament. Our purpose has been simply to undergird these Christological treatments with the exegetical demonstration that, despite recent arguments to the

111 See above p. 31.

112 See above pp. 34-36.

113 Pp. 38-39.

11 $C f$. for a similar conclusion, A. J. B. Higgins, Jesus and the Son of Man, 196-197. 
contrary, Isaiah 53 did in fact play a central role in Jesus' view of His own redemptive work.

To avoid misunderstanding, however, it must be pointed out that the arguments we have used are not in any way intended to belittle the importance of the Son of man of Daniel 7:13 in Jesus' self-estimation. There are, as we have stated, more frequent actual allusions to this figure in the sayings of Jesus than to any other in the Old Testament, quite apart from the fact that this passage is the most probable source of Jesus'

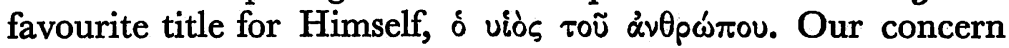
has been to prevent the recognition of the centrality of this figure overshadowing, and indeed virtually eliminating, the equally important figure of the Servant of Yahweh. Each has a distinctive role to play in Jesus' view of His mission. Nor are they alone; several other messianic figures of the Old Testament, and several non-messianic figures typologically applied, each add their distinctive shade to the many-coloured tapestry which is Jesus' own Christology.

The two dominant figures, however, are the Servant of Yahweh and the Son of man. This is no new discovery. Many scholars have seen in the combination of these two themes the most original and distinctive aspect of Jesus' application of the Old Testament to Himself. 115 Our study serves to underline this traditional account. While Jesus is destined, as Son of man, to receive power and glory and an everlasting dominion from the Ancient of Days, His route to this ultimate goal must lie through the vicarious and redemptive suffering and death of the Servant of Yahweh. Isaiah 53 is the blueprint for His earthly ministry, Daniel 7:1 3-14 for His future exaltation, and it is to those phases of His mission respectively that He applies the two passages. To suggest that $\mathrm{He}$ derived not only the future glory but also the earthly suffering from Daniel 7 is not only inconsistent with His actual use of that passage, but also robs His self-understanding of its most distinctive feature, the combination into a single programme of the contrasting fates of the Servant and the Son of man. It was this combination that resulted in the teaching which took even His own disciples by surprise, that

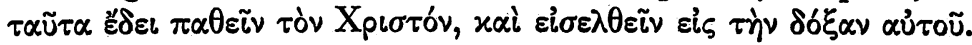

116 For some typical statements of this view see V. Taylor, Jesus and His Sacrifice, 32, 48, I1 3, 258-259, 282; W. Manson, Jesus the Messiah, Hodder and Stoughton, London (1943) I $17-1$ I 8; S. Mowinckel, op. cit., 448-450; O. Cullmann, Christology, 158-161; C. H. Dodd, op. cit., 119; A. Richardson, op. cit., 135, 145; N. Perrin, The Kingdom of God in the Teaching of Jesus, SCM, London (1963) 106-107. 